\title{
The Rhetoric of Begin: Leadership in Changing Times
}

\author{
David Schwartz \\ Bar Ilan University, Ramat Gan, Israel \\ Email: dvd99@015.net.il
}

How to cite this paper: Schwartz, D. (2016). The Rhetoric of Begin: Leadership in Changing Times. Open Journal of Leadership, 5, 84-94.

http://dx.doi.org/10.4236/oj1.2016.53008

Received: August 17, 2016

Accepted: September 19, 2016

Published: September 22, 2016

Copyright $\odot 2016$ by author and Scientific Research Publishing Inc. This work is licensed under the Creative Commons Attribution International License (CC BY 4.0).

http://creativecommons.org/licenses/by/4.0/

\begin{abstract}
A precise examination of Menachem Begin's speeches and history over the years reveals that Begin's rhetoric constituted a political instrument that he knew to change according to the circumstances. Begin's rhetoric was controversial, as he went from the leader of a terrorist organization, was awarded a Nobel Peace Prize, and was the Prime Minister who signed the peace treaty with Egypt. This quality study claims that begin's rhetoric is integral part of his personality and of his leadership. The assumption is that like a typical politician his leadership changed according the winds of times. His charisma and transformational leadership made him a great leader. His rhetoric constituted just instrument for justification his political actions. Begin was revealed to be pragmatic, in contrast to the militant images that his political rivals attempted to affix to him.
\end{abstract}

\section{Keywords}

Rhetoric, Leadership, Begin, Herut Party, Likud Party

\section{Introduction}

This article examines the rhetoric of one of the most significant leaders of Israel Menachem Begina leader that made a long way from terrorist to prime minister.

The study deals with his abilities as a leader in order to use the rhetoric's as an instrument to get to his political position.

The article refers to the Research Literature In the field of leadership and rhetoric and the consequences of these two ingredients and to the personality of Beginas a political leader.

The assumption of the study is that Begin as a politician used his verbal abilities in order to get his political targets. 
And that the wings of history and times made the effect on him.

Begin has been one of the most significant leaders of Israel since its establishment, as prime minister (1977-1983). His personally conducted the country's foreign policy leading first the Camp David Accretes in 1978 and then to the Egypt-Israel peace treaty in 1979. He has the ability to articulate a general approach to Israel's problems, a right wing philosophy that still prevails in many quarters (Reich, 1990).

His leadership began very soon from his early days, and it leaned on combination of strong self-belief and impressive ability to speak and to convenience. This study examines it. The charisma of Menachem Begin was expressed in his speeches and relied primarily on his oratory ability (Schwartz, 1991).

\section{Literature Review}

\subsection{Leadership}

A leader is one or more people who selects, equips, trains, and influences one or more follower(s) who have diverse gifts, abilities, and skills and focuses the follower(s) to the organization's mission and objectives causing the follower(s) to willingly and enthusiastically expend spiritual, emotional, and physical energy in a concerted coordinated effort to achieve the organizational mission and objectives. The leader achieves this influence by humbly conveying a prophetic vision of the future in clear terms that resonates with the follower(s) beliefs and values in such a way that the follower(s) can understand and interpret the future into present-time action steps. In this process, the leader presents the prophetic vision in contrast to the present status of the organization and through the use of critical thinking skills, insight, intuition, and the use of both persuasive rhetoric and interpersonal communication including both active listening and positive discourse, facilitates and draws forth the opinions and beliefs of the followers such that the followers move through ambiguity toward clarity of understanding and shared insight that results in influencing the follower(s) to see and accept the future state of the organization as a desirable condition worth committing personal and corporate resources toward its achievement (Winston \& Patterson, 2006).

Sergiovanni (1992) presented a theoretical framework consisting of five sources of authority for leadership: bureaucratic authority, psychological authority, technical-rational authority, professional authority, and moral authority, like in the case of our study.

Another sort of leadership is the transformational leadership is defined as the combination of four attributes; Charisma; a force to create and present positive futuristic vision; inspirational motivation; an inspirational spirit to motivate the followers to reach out beyond their self-interest; Intellectual stimulation; a spirit to prompt the followers to see the issues from a novel perspective to offer solutions; individualized consideration; an ability of the leader to develop the follower through encouragement, support and mentoring. First introduced by Burns (1978) and later elaborated by Bass (1985) the basic logic behind the transformational leadership. Begin's leadership was such as describe, he transfer his party from opposition to power, and influence hisfol- 
lowers to support the way of peace, instead of the old way of the right wing.

\subsection{Rhetoric}

Oratory, the art of persuasion, is a part of politics. When Aristotle authored "Rhetoric", at the end of the fourth century BC, oratory was at its peak development. Beyond the active use of the ability of speech in politics and law, written versions of important speeches from the present and past were widely found. Schools for oratory flourished, and wandering teachers disseminated the art. The skill of speaking and persuasion was a necessary element in the education of every free citizen. However, rhetoric also awakened attitudes of suspicion, criticism, and total rejection, primarily because of different demagogic and sophist trends that were encouraged by it (Aristotle, 2002).

In Europe of the $19^{\text {th }}$ century the art of rhetoric developed as a tool in the hands of the totalitarian regimes. The Communist Revolution in 1917 influenced all the political parties with the rhetoric enthusiasm Lenin adopted to promote the revolution. The oratorical methods of Lenin and Trotsky influenced the leaders from the entire political range and obviously those who lived then in Europe (Brown, 2012). Jabotinsky, who constituted Begin's model of leadership, was greatly influenced by the socialist and communist rhetoric prevalent in his period in Europe (Shechtman, 1959).

Rhetoric generally is associated with populism, or in other words, with movements that want to win the people's hearts. According to Pilk (2005), the Likud Part is a populist movement that acted to end the hegemony of the Labour movement and Begin, as its leader, is a populist, or in other words, without an ideological backbone.

\section{Begin Leadership and the Influence on His Rhetoric in Changing Times}

\subsection{Begins Background}

Menachem Begin was born in the year 1913 in the city of Brest-Litovsk, a city on the border of Poland that today is in Belarus, and died in the year 1992 in Jerusalem. He underwent a long period of socialization, from his childhood in a peripheral region, the commander of Beitar, the youth movement that Jabotinsky founded, study of law in Warsaw, activity in the Revisionist movement, the Nazi conquest of Poland, the Holocaust, the murder of his parents by the Germans, his time as a commander in the underground that operated against the British, and then a leader of the a right political movement and leader of the opposition to the Labour governments of Israel, until after eight failures in the elections to the Knesset he reached the position of Prime Minister. Begin led the first change of government in the State of Israel against the Labour movement, which dominated in the State of Israel until 1977.

Begin changed his ideological path (Weitz, 2003), from the support of Greater Israel to the surrender of territory and the Camp David Accords, in which he agreed to recognize the rights of the Palestinian nation and to grant autonomy. In his later years, he protected the legal system, since he had always supported the rule of law, and displayed state responsibility (Barak, 2013). He saw the supremacy of law as protection against 
the tyranny of the executive (Neor, 2007).

Menachem Begin came a long way from the commander of the underground movement the Irgun TzvaiLeumi to the leader of a political party in the Israeli Parliament, which accepts upon itself the rules of the political game, at first as a combative opposition, then when he established the Liberal-Herut bloc, along with the Liberal Party. He was a responsible opposition. Later with approach of the Six Day War he joined the government headed by Levi Eshkol, and then, given differences of opinion on the status of the territories of Judea and Samaria, he returned to the opposition, until he reached the chair of Prime Minister in 1977. Over the years he adjusted himself to changes in the political map and even became more moderate. As he drew closer to the government, his rhetoric became more moderate, as he was on the way to his legitimacy as a "responsible leader" (Shilon, 2010).

\subsection{Begins Leadership}

Menachem Begin, the Israeli Prime Minister who made peace with Egypt, lived much of his life in the opposition. A Jewish underground leader before Israel gained independence in 1948. He openly fought the established Zionist leadership of the struggle against British rule.

Then for nearly three decades, he headed Israel's major opposition party.

Ultimately and to many Israelis, surprisingly, his minority bloc ousted the Labor Party, which had governed continuously in the three decades since statehood, Begin, as party leader, became Prime Minister. He was to govern an ever more divided and troubled nation.

Mr. Begin, who led Israel from May 1977 until he resigned as Prime Minister in 1983, stretched the national mood from great pride to deep dismay. He guided the nation to a peace treaty with Egypt, the first such pact with an Arab country. But he also presided over a bitterly divisive war against Palestinian guerrillas in Lebanon.

If the treaty with Egypt, which brought Begin a shared 1978 Nobel Peace Prize with President Anwar el-Sadat, represented a high point in his political leadership, the war in Lebanon in 1982 and the stalemate that followed, with its steady toll of dead and wounded, were its low point.

Started with the announced aim of evicting Palestinian guerrillas from operating too close to Israel's border with Lebanon, it brought Israeli troops to the outskirts of Beirut. It enmeshed Israel in the lethal sectarian politics of Lebanon, and led to a costly and indecisive occupation.

The invasion in June 1982 was seen by Israelis at first as a justified response to years of border harassment. But when the Israelis advanced to the outskirts of Beirut and bombed and shelled the Lebanese capital for 10 weeks, criticism and anguish arose.

Dissent reached a peak in the fall of 1982, when Lebanese Christian militia units entered Palestinian refugee districts at Sabra and Shatila that were supposedly under Israeli guard and killed hundreds of people.

The massacre led to an independent investigation ordered by the Israeli Government, 
which concluded that Israeli troops watched the killing from a distance and did nothing to stop it. Begin survived in office, but was shaken politically.

His medical problems-he had suffered three heart attacks-became an increasing burden. And in November 1982, his wife of 43 years, Aliza, died while he was on a trip to the United States. Thereafter, Begin became increasingly listless, participating little in debate in Parliament, taking less and less interest in politics and limiting his public appearances. On Aug. 28, 1983, he announced that he planned to quit and on Sept. 15 he formally resigned as Prime Minister (Feron, 1992).

\subsection{The Rhetoric of Begin}

Oratory is an ancient discipline. In a speech, as Nadava stated, "A person collects words, combines them with one another, and in a way that cannot be investigated they shine with life, the person has in his hands not a sentence, but a song, a discovery, a new creation, the joy of the world." (Nadava, 1957).

Oratory has existed since the person learned to speak. The main point of rhetoric, the art of speech, is to convince or tempt (Nadava, 1957). It is possible to define rhetoric as a "means of persuasion for change" (Landau, 1988).

Menachem Begin was prominent as an artist of oratory in Israeli politics. He was more than once accused that "his speeches are loaded with 'fire and brimstone" (Preuss, 1982).

A number of factors influenced Begin. First, he was influenced by the personality of Jabotinsky, the greatest of the orators of Zionism. Begin saw himself as "the messenger who brings the message from the world of Jabotinsky" (Schwartz, 1991). The education in Beitar and the Beitar glory shaped his personality. Begin saw himself as the successor of the head of Beitar, Jabotinsky, who was renowned as the greatest of orators in the Zionist movement. Begin presented himself as one of Jabotinsky's students and mentioned him in almost every one of his speeches.

Conversely, Begin's political opponent, Ben Gurion, built for him an image of a warmonger, a "fascist", a factor that constitutes a danger to the rule of law, who attempted to perform a "military putsch", by bringing the ship, "Altalena". Ben Gurion addressed Begin as "the man who sits beside Dr. Bader", and left the plenum every time that Begin rose to speak. Begin was required all the time to adjust himself to the political system.

When Begin greeted President Sadat, he took pains to mention that already the first Prime Minister of Israel, Ben Gurion, had called for peace with all the neighboring Arab countries (Schwartz, 1991).

The public images of Begin constituted a part of the rhetoric that characterized Begin and thus his opponents and supporters. At first he was perceived as a "terrorist", because of his activity as the Etzel commander and as responsible for actions such as "blowing up the King David Hotel", "Dir Yassin", and "Altalena". In the first incident, Jews who stayed at the hotel were accidentally injured, in the second incident residents of the Arab village were injured, and in the third incident the Mapai government de- 
picted him as about to spark a revolution. When he reached the government, many feared that he would immediately go to war (Schwartz, 1991).

Another image that stuck to Begin was the "formalist", since Begin, who had studied law in Poland, tended to integrate in his speeches legal aspects. With the exception of the Reparations Agreement, when Ben Gurion consented to receive reparations from the German government a short time after the Holocaust, in most cases the legalist approach and his belief in the rule of law were prominent. This was also the case in the precision he displayed in the formulation of the peace treaties with Egypt.

Begin's oratory ability was not disputed. In his speeches he tended to dramatization. He even burst into tears after the Altalena was blown up. Weitzman maintained that Begin's life tool was the speech and that "every moment in his opinion was historic" (Schwartz, 1991).

Begin created through his oratory a relationship with the masses. This was the case with the famous speech in the Zion Square, on the matter of the reparations, following which stones were thrown at the Knesset.

His speeches connected him to the members of the Eastern Jewish communities, from the WadiSalib riots to the speech of the "Tzachtzachim", when he spoke out against Dudu Topaz (Goldstein, 2007).

Shapira noted that Begin dedicated most of his actions to speeches, which were the main event in all the committees of the Herut Movement (Shapira, 1989).

The election propaganda of the Herut Movement used images, such as the "good people", members of the Herut Movement, versus the corrupt Mapai government, through caricatures, explanation campaigns (Gravis, 2011). However, the rhetoric of Begin in all of his speeches constituted the most effective explanatory tool that presented the battle of "the few against the many" (Gratz, 1983).

In addition to his party and the public at large, the Knesset was the primary state arena for his speeches. In the Knesset, Begin found a home and base for his actions. It became for him a state stage for his speeches on the Land of Israel.

One of his speeches was among the best the Knesset has known. For long years he worked to change his image as anti-democratic. Gradually his style hanged, and the orator of the street intersections, who thrilled crowds, became a sharp-tongued debater. He became an artist of wording and compromise without surrendering his basic principles.

His years in the opposition desert and the disappointments inflicted on him by the voters taught him that there was no chance to reach the government on the platform of Herut and that he needed to forge political alliances conditioned on compromises.

The change in him was slow, but over time he became one of the significant parliamentarians in the Knesset. He learned the rules of the Knesset and the power of the institution of the query and the use of interruptions, the possibilities of action in the committees, the power of witty phrasing. He called the Knesset the "supreme expression of the people's will" (Schwartz, 1991).

Begin attributed importance to service in the opposition. He brought with him in his 
speeches the shadow of the past: the Holocaust, the Season, the debate on the reparations from Germany. After the Ben Gurion era, Begin reached the status of the number one debater in the parliament. He was attributed the degree of parliamentarian of moods. In times of desperation he sought unity and pacification, and in good times he surpassed himself in his stylish appearance seasoned with quotes, gestures, and catchphrases in the Knesset plenum.

In his last years often Begin turned inwards and avoided public appearances.

Weiss maintained that the Begin era was characterized by a merger between formal democracy and a monarchal mentality and that in his movement there was no person to halt the spread of the spirit of monarchy (Schwartz, 1991).

However, he proved that he was capable of self-criticism and knew also days of torturous criticism.

"He who incited and excited the masses was gifted by brakes completely absent from his immediate political environment. This caused him soul-searching, at the time of the Lebanon War." (Schwartz, 1991).

Begin was faithful to the rules of democracy and succeeded in promoting his party even at the expense of ideological surrenders, which brought him into "respectable society, the salons of the Israeli bourgeoisie, no longer as "the city madman" as he was called by the first editor of Maariv, Carlebach, who spoke out against him after stones were thrown at the Knesset during the Reparations Incident.

Slowly Begin's image became more moderate, and he became the "great-grandfather". In the 1977 elections the campaign manager Weitzman attempted to portray him as an exemplary family man, as an affable grandfather, who lives a modest life in his basement apartment, a humane and popular person, no longer a man of war (Schwartz, 1991).

Some criticized Begin as a person who tends to great gestures, who is interested in entering history and perceiving the historical dimension (Schwartz, 1991). However, all these constituted factors of motivation on the one hand for the peace treaties with Egypt and on the other hand for the attack of the nuclear reactor in Iraq.

Two factors of influence on Begin's rhetoric were entwined throughout his life, Judaism and the Holocaust, in addition to other influences. Begin had a Zionist Jewish education from his father, who served as the secretary of the Jewish community in Brest Litovsk. He was "compelled by tradition and worship", as Bader noted. He maintained that "Begin's rationalism submitted to his almost mystical belief. He loved the religious lifestyle of his parents' home" (Schwartz, 1991).

On the eve of the revolution of May 17, 1977 "he took from his pocket a large black kippa (yarmulke), put it on his head, and read verses from the book of Psalms: 'Blessed is God for hearing my pleas... for redeeming your people and blessing your inheritance, and tend them and carry them forever.' It was a complete innovation in the political scene of Israel. Never had an Israeli Prime Minister spoken in such dramatic terms. Never had he read Bible verses and never had he thanked God for victory in the elections." (Neor, 1993). 
Through religious images Begin appealed to the traditional community and to people of the Eastern communities (Lavi, 2016).

The traumatic event of the Holocaust, in which he lost his parents and his brother, constituted a dominant event that influenced Begin's rhetoric discourse. He himself managed to escape the clutch of the Nazis and was imprisoned by the Soviets for his Zionist activity.

Begin, who remained alive only with his sister, lived in the shadow of the Holocaust. In 1952, when Ben Gurion signed the Reparations Agreement, Begin believed that "Nothing in the world justifies negotiations with the German murderers." (Schwartz, 1991).

When the Reparations Crisis occurred, he neglected his belief in the rule of law and called: "We will announce that we will not pay taxes to a government that negotiates with the Germans. Either German money or Jewish money, both together are not possible." (Schwartz, 1991).

He called Ben Gurion, the Prime Minister at that time: "The little tyrant and the great maniac who does not take into account the depth of the Holocaust and the severity of the danger." (Schwartz, 1991).

On this matter, Begin really was wild: "This is one of the things for which we must sacrifice all, we will leave our families, we will say goodbye to our children." (Schwartz, 1991).

Begin objected to every type of relationship with Germany. "Can the relations between us and the Germans be normal as if there had been no destruction?" (Schwartz, 1991).

Over time, his approach became more moderate even in this field, and when he was appointed Prime Minister, he met as accepted with the German ambassador in Israel and then with a representative of the German Bundestag.

Although he obviously felt discomfort, he said, "I announced that I would fill all my state roles and I am doing so at the moment." At the time of the conversation, he reminded his guest of the deeds of the German people at the time of the Holocaust and was careful to speak only in the English language (Schwartz, 1991).

When he met with the German Foreign Minister he emphasized, "When speaking about relations between the countries, it is necessary to see things in the broad context, in other words, the relations between the Jewish people and Germany and not necessarily between Germany and Israel."

This approach appeared to his personal secretary as pragmatism and realpolitik, which surmounted ideals that cannot be fulfilled.

Begin's reliance on the Holocaust was expressed also in the implementation of his policy. In the letter Begin sent to the President of the United States on August 1982, when the Israel Defense Force (IDF) was in Beirut, he drew an analogy between Hitler and Arafat, "I feel as the Prime Minister like the alliance forces fighting in Berlin." (Schwartz, 1991).

Obviously Begin was also influenced by the spirit of Polish nationalism, in which Re- 
visionism and the Beitar youth movement developed and formed. In Poland the Zionist leadership sought to learn how to conduct a politics of national pride and power, although from a realistic perspective it was not in a similar position.

The Beitar members in Poland wanted to establish an organization with the main role of preparing its members to be soldiers for the homeland. They were convinced that a military struggle was the only way to political independence.

Jabotinsky tended to see the very existence of a military force such as the Jewish Brigades and then the Irgun as a factor that would influence the British to allow the Jews to establish a state. However, he did not expect that Beitar itself would create a military force to fight for the country, even against the British.

Beitar and Begin improved Jabotinsky's orientation through the Irgun, which challenged the British. Begin, in his actions in the Irgun, was revealed not only as an orator but also as a man of organization and action.

Begin came a long way from being a Zionist propagandist in Poland and a militant underground leader in the war for the rebirth of Israel till he became the Prime Minister of Israel. Years of political isolation made him more moderate.

In the 1940s he was a politician for whom nationalism, independence, and the existence of the people were perceived not only as empirical facts but also as an ideological reflection of belief in legal justice and proof that the existence of the nation depends on its desire to fight for this.

In contrast, when he was appointed as Prime Minister, he became more moderate, and did not act as "a prophet who remonstrates at the gate". Over the years Begin built his image as a national hero, a Jewish Garibaldi. "On the street and in the Parliament he extended his rhetoric wings as a populist leader" and reached people who were not interested in doctrinal explanations. As opposition leader, Begin offered something for everybody: he was a war hero, he was a national Zionist in Poland, he was persecuted by Stalin, and he was a believer linked with every fiber in his soul to religion.

In 1977 Begin already was different from what he was in 1935 or even 1949. Bader noted, "He became quieter in his appearances, more deliberate, more cautious and restrained in his speeches, he learned a lot", and then added, "He accumulated great experience, he did not stop being faithful to his principles but in addition he became a clever politician, flexible, experienced: an opportunist in tactics, a fundamentalist in strategy." (Schwartz, 1991).

Ya'akov Meridor, who transferred the command of the Irgun to Begin and was his partner in the political path, noted in this context, "From the moment that Begin was chosen to wear the mantle of the Prime Minister he had to take care of the entire nation of Israel, from a national and historical perspective he could not be the same person, since this responsibility forces on you sometimes a contradiction with the outlooks you held for many years. You must weigh the entire picture." (Schwartz, 1991).

Today the discourse has become poorer in terms of the language, following the transition to electronic media such as email and the use of smartphones, which lead to the use of short and concise messages. 
The reasonable politician today is helped by experts to manage a political campaign. Some of these experts are imported from abroad, and they build the organization of the arguments and the presentation (Meor, 2008).

The politician builds for himself an image using counselors, spokespersons, image offices, and public relations. In the era of television media, the writer, the editor, and the photographer often influence more than the contents of the public official (Meor, 2008).

\section{Conclusion}

Today, we long for the language, style, gestures, color, richness, and melody that characterized Begin's speeches. Many feel that the characteristics of discourse entailed by rhetoric, in other words, the art of oratory, emphasis on the contents and the language, the charismatic personality, have vanished from the map of public discourse and given way to shortened television language, shallow, which suits itself to the technological media, which necessitates short messages that meet the timeframes and broadcast schedules dictated by the advertisers and the desire to attain a high rating.

Today is the era of the "tele-politicians" (politicians who adjust themselves to the television), as Galili notes (Galili-Zucker, 2004), and the not the days of the great orators in Zionism who aspired like Begin and Jabotinsky to be the saviors of Zionism and the bearers of the national vision.

Begin knew to adjust himself to every political situation. He was once a "tribune of the masses", once the defender of the weak, and once the responsible figure who maintained the rule of law. In his last days, he was Prime Minister from the Likud Party. In the end, he was the tragic figure after the First Lebanon War, when he chose to retire and decided to maintain a long silence.

A person for whom his entire life the tool of oratory was the main tool, suddenly Begin decided to maintain a thunderous silence and retired to his home, where he secluded himself to his last day.

Begin's rhetoric changed according to the needs and political circumstances. The rhetoric did not lead Begin; rather, he led the rhetoric. Begin's leadership was transformational leadership. He transferred his party from opposition to power. Thus, there is room for additional research studies that indicate the relations between the psychological aspects and the verbal abilities of the leader as well as the environmental influences on the leader's rhetoric.

\section{References}

Aristotle (2002). Rhetoric. Translated by: G. Tzoran. Tel Aviv: SifriatPoalim.

Barak, A. (2013). The Rule of Law through the Supremacy of the Law, In: D. Ben Yosef (Ed.), The Separation of Powers and the Supremacy of Law in Israeli Democracy in the View of Menachem Begin (pp. 1-50). Jerusalem: Begin Heritage Center.

Bass, B. M. (1985). Leadership and Performance beyond Expectations. New York: Free Press. Brown, A. (2012). The Rise and Fall of Communism, Translated by: C. Guy. SifriatOfakim: Am 
Oved.

Burns, J. M. (1978). Leadership. New York: Harper \& Row.

Feron, G. (1992) Menachem Begin, Guerrilla Leader Who Became Peacemaker. The New York Times. http://www.nytimes.com/learning/general/onthisday/bday/0816.html

Galili-Zucker, O. (2004). The Tele-Politicians: New Political Leadership in the West and in Israel. Tel Aviv: Ramot Press.

Goldstein, A. (2007). Menachem Begin, the Herut Movement, and Social Protest: Between WadiSalib and the Black Panthers. Israel 12.

Gratz, N. (1983). Few against Many-Rhetoric and Structure in the Election Speeches of Menachem Begin. Question Mark 16-17 (pp. 106-126).

Gravis, K. A. (2011). Between Propaganda and Explanation-Election Propaganda of the Herut Movement (1948-1961). In: A. Diskin (Ed.), From Altalena to Here Jerusalem (pp. 92-116). Carmel: Menachem Begin Heritage Center.

Landau, R. (1988). The Rhetoric of Parliamentary Speeches in Israel. Tel Aviv: Aked.

Lavi, D. (2016). The Begin Code. Jerusalem: The Begin Center, Keter.

Meor, A. (2008). What We Learned from Arthur Finkelstein. Tel Aviv: Zarlev.

Nadava, Y. (1957). The Doctrine of Oration. Tel Aviv: Hadar.

Neor, A. (1993). Begin in Government Personal Testimony. Tel Aviv: Yediot Acharonot.

Neor, A. (2007). On the Opinion Journalism of Menachem Public (p. 36). Connection.

Pilk, D. (2005). Populism and Hegemony in Israel. Tel Aviv: Hakibbutz Hameuchad.

Preuss, T. (1984). Begin-His Regime. Jerusalem: Keter.

Reich, B. (1992). Political Leaders of Contemporary Middle East and North Africa (p. 71). New York: Greenwood Press.

Schwartz, D. (1991). From Opposition Party to Governing Party, the Herut Movement. PhD Dissertation, Jerusalem: The Hebrew University.

Sergiovanni, T. J. (1992). Moral Leadership: Getting to the Heart of School Improvement. San Francisco, CA: Jossey Bass.

Shapira, Y. (1989). We Voted for the Government. Tel Aviv: Am Oved.

Shechtman, Y. (1959). Zeev Jabotinsky: His Life. Tel Aviv: Karni Press.

Shilon, A. (2010). Begin-1913-1992. Tel Aviv: Am Oved.

Weitz, Y. (2003). From Etzel to Gahal: Themes of the Herut Movement, Studies in the Revival of Israel (Vol. 13).

Winston, B. E., \& Patterson, K. (2006). An Integrative Definition of Leadership. International Journal of Leadership Studies, 1, 6-66. 
Submit or recommend next manuscript to SCIRP and we will provide best service for you:

Accepting pre-submission inquiries through Email, Facebook, LinkedIn, Twitter, etc. A wide selection of journals (inclusive of 9 subjects, more than 200 journals)

Providing 24-hour high-quality service

User-friendly online submission system

Fair and swift peer-review system

Efficient typesetting and proofreading procedure

Display of the result of downloads and visits, as well as the number of cited articles

Maximum dissemination of your research work

Submit your manuscript at: http://papersubmission.scirp.org/

Or contact ojl@scirp.org 